$\mathrm{SH}$

167

S17M65

1883

FISH

ISSUED BY AUTHORITY

UIVISIOATIONAI NUSEUM?

DIVISTON OR MISEES

PAPERS OF THE CONFERENCES

Held in connection with

The GREAT JWTERTITONAL

FISHERIES EXHIBITION

\title{
SALMON
}

AND

\section{SALMON FISHERIES}

BY

DAVID MILNE HOME, Fx $\mathrm{R}_{x} \mathrm{~S}_{x} \mathrm{E}_{x}$ OF MILNE-GRADEN (BERWICKSHIRE)

\section{LONDON}

7D WILLIAM ClOWES AND SONS, LIMTTED INTERNATIONAL FISHERIES EXHIBITION AND 13 CHARING CROSS, S.W. 


\section{PAPERS OF THE CONFERENCES}

\section{Held in connection with the GREAT INTERNATIONAL FISHERIES EXHIBITION.}

\section{NOW READY}

Demy 8vo., in Illustrated Wrapper. Price Sixpence each.

INAUGURAI MEFTING: ADDRESS. By Professor HUXLEY, P.R.S. H.R.H. the PRINCE OF WALKS (P esident of the Commission) in the Chair.

NOTES ON THE SEA FISHERTES AND FISHING POPULATION OF THE UNIL'ED KINGDOM. By H.R.H THE DUKE OF EdINBURGH, K.G. is.

THE FISHFRY INDUSTRIES OF THE UNITED STATES. By Professor BRown GoOde, M.A.

OYSTER CULTURE AND OYSTER FISHERIES IN THE NETHERLANDS. By Professor HuBRECHT.

PRINCIPLES OF FISHERY LEGISLATION. By Right Hon. G. SHAwLRFEVRE, M.P.

ON THE CULTURE OF SALMONIDAF AND THE ACCLIMATISATION OF Fish. By Sir James Ramsay Gibson Maitland, Bart.

FISH DISEASES, By Professor HUXLEY, P.R.S.

THE FCONOMIC CONDITIOIN OF FISHERIMEN, By Professor LEONE LEvi.

THE FISHERIES OF CANADA. By L. Z. JoNCAS.

PRESERVATION OF FISH LIFE IN RIVERS BY THE EXCLUSION OF TOWN SEWAGE. By the Hon. W. F. B. MASSEY MaINWARING.

MOLLUSCS, MUSSELS, WHELKS, \&c., USED FOR FOOD OR BAIT. By Charlits HARDing.

COARSE FISH CULTURE. By R. B. MARSTON.

ON THE FOOD OF FISHES. By Dr. F. DAY.

THE HERRING FISHERIES OF SCOTLAND. By R. W. DUFF, M.P.

IIINE FISHING. BY C. M. MUNDAHL.

FISH TRANSPORT AND FISH MARKETS. By His Excellency SPENCER WALPOLE.

FOREST PROTECTION AND TREE CULTURE ON WATER FRONTAGES. By D. Howstz, Esq.

SEAL FISHFRIES. By Captain TEMPLE.

FISH AS FOOD. By Sir HENRY THOMPSON.

STORM WARNINGS. BY R. H. SCOTT.

ON THE DFSTRUCTION OF FISH AND OTHFR AQUATIC ANIMALS BY INTERNAL PARASITES. By Professor COBBOLd, F.R.S., F.L.S.

SCIFNTIFIC RESULTS OF THE FXHIBITION, By Professor E. RAY LANKRSTER.

A NATIONAT FISHERY SOCIETY FOR GREAT BRITAIN. 'By C. E. FRYER.

CRUSTACEANS. BY T. CORNISH.

TRAWLING. BY ALFRED ANSEll.

THE BASIS FOR LEGISLATIOIN ON FISHERY QUESTIONS. By Lieut. Col. F. G. Solí.

MACKEREL AND PILCHARD FISHERIES. By T. CORNISH.

ARTIFICIAL CULTURE OF LOBSTERS. By W. SAVILLE KENT.

FRESHWATER FISHING (other than Salmon) By J. P. WHEELDON.

SALMON AND SAIMON FISHERIES. By DAVID MILNE HOME, F.R.S.E.

\section{IN THE PRESS.}

ON FACILITIES FOR THE IMPROVED CAPTURE AND ECONOMIC TRANSMISSION OF SEA FISHES, AND HOW THESE MATTERS AFFECT IRISH FISHERIES. By R. F. WALSH, of Kinsale.

THE FISHERIES OF IRELAND. By J. C. BLOOMFIELD.

THE FISHERIES OF OTHER COUNTRIES. By Commissioners for Sweden, Norway, Spain, \&c., who took part in the Conference. 
1883 International Fisheries Exhibition FISH

\section{O N D O N, I 883}

\section{$\underline{\text { SA L M ON }}$}

AND

\section{SALMON FISHERIES}

BY

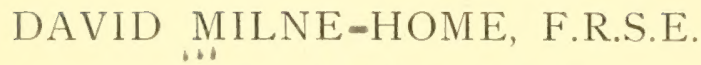

OF MILNE-GRADEN (BERWICKSHIRE).

\section{LONDON}

William Clowes AND SONS, Limited INTERNATIONAL FISHERIES EXHIBITION AND 13 CHARING CROSS, S.W. 



\section{International Fisheries Exhibition L O N D O N, I 883}

Conference on Tuesday, July i7, 1883.

The LORD LOVAT in the Chair.

The Chairman, in introducing Mr. Milne Home, said the work of the Exhibition would not have been complete if a paper on that most noble of our fish, the salmon, had been omitted. The importance of the salmon was very great, supporting as it does a considerable industry, supplying a vast amount of food, and affording the finest sport which in this sporting country a sportsman could enjoy.

\section{SALMON AND SALMON FISHERIES.}

If the announcement in the Programme of this day's Conference means that there is to be an account given of the Salmon and Salmon Fisheries of the United Kingdom, I fear that any information I can furnish will not do justice to the subject ; for my knowledge of Salmon and Salmon Fisheries is derived only from my experience as a proprietor of salmon fisheries in one river in the south of Scotland, viz., the Tweed; and from having had some share in managing the fisheries of the river, and of the sea-coast on each side of its mouth.

But as, according to the latest known returns, the Scotch Salmon fisheries are, in value and produce, fully one-third of those of the United Kingdom, and there are peculiarities 
in the Scotch fisheries which seem deserving of attention, I venture to offer a few remarks for the consideration of the Conference.

\section{FISH.}

There are several kinds of salmon in the Tweed. The most common are the Salmo salar, or true salmon, and the Salmo eriox, which last kind is known also by the names of bull-trout, sea-trout, or whitling. But there are hybrids which sometimes render identification difficult.

The young of the true salmon, when first hatched, we call a "parr," having dusky cross bars on its sides. Hatched in December or January, these "parr" go slowly down the river towards their ultimate destination, the sea. But they do not venture into the sea till another skin of glistening scales has been formed over their first skin. They then receive the name of "smolts." . If put into salt water, before getting this silver dress, they die. It is only a portion of the "parr" which go to sea during the first year. The rest, being probably more weakly in constitution, remain in fresh water till the following spring, when, if not devoured by natural enemies, they also put on a silvery dress, and betake themselves to the ocean.

The " smolts," after remaining in the sea for some months, return to their native river, having grown to about twelve inches in length, and weighing about half a pound or more. They then go by the name of "black-tails," having the tail and the dorsal back fin of a black colour. They hover about the lower parts of the river, not going far beyond the influence of the tide. Before winter they return to the sea; and in the following year they come back to the river as grilse in June and July. For what purpose they come then is not yet known. When they come in September and October, it is in most cases to 
deposit ova and milt in the spawning beds. After they have spawned they return to the sea, and if they come back next year, my opinion is that it is in the form of a salmon-a change corresponding to that of the heifer into a cow after her first calf. This, however, is one of the points on which naturalists differ.

The young of the bull-trout are like the young of the true salmon-first parr and then smolts. When they return from the sea, they go to the higher parts of the river, and are known as "orange-fins," being distinguishable by a yellow colour on the belly.*

It would appear that many of the grilse and salmon, though sufficiently advanced in life, remain sterile. In the months of December and January, which is the usual time for spawning, quantities of adult salmon are seen by cod, haddock, and herring fishermen, twelve and fifteen miles from the coast, near the surface of the water, playing about, as the fishermen term it, probably being then in pursuit of food. Even in the river, during the above

* There is, however, a little uncertainty regarding the relative positions of "Orange-fin" and "Black-tail." Some young fish, believed to be Orange-fins, having been put into a pond at Carham, and kept there for two or three years, were examined by Mr. Stirling, of Edinburgh University, and he reported on them as follows.

A fish, weighing about 2 lbs., having been examined, Mr. Stirling suggested the following account of its life history :-

"It was put into the pond in May, I874, as an Orange-fin.

"It became a Black-tail in May 1875 .

"It became a Bull-trout in November, 1876 .

"It spawned about this time.

"Its progeny were hatched in February 1877.

"Its progeny became Parr in May 1877.

"Its progeny became Orange-fins in April I878."

Mr. Stirling was therefore of opinion that the fish known as an "Orange-fin" in the Tweed, is the "Black-tail" of that river in a younger stage. 
months, adult salmon have been seen, not seeking the spawning beds, but lying in deep pools.

In the Tweed, there have been numerous well-authenticated cases of salmon having been caught exceeding 70 lbs. in weight (see 'Tweed Salmon Reports,' published by Blackwood, Edinburgh, in I867, p. I21).

With regard to the food of the salmon, I have never heard of anything having been found in their stomachs, except what they must have got when in the sea. Small haddocks, cod, and herrings have been found, as well as lugworms, sand-eels and remains of jelly-fish. The seafishermen believe that when in salt water they feed largely on "Mather," or “Herring Sile," minute crustaceans, which are often in such quantities as to colour the water, and which generally betoken to the fishermen the proximity of herrings. Even when salmon are taken in parts of the river, at a distance of above twenty miles from the sea, as at my own residence on Tweedside, they have been found with small herrings in their stomach, as the only appearance of food. When they come into the river to spawn, my belief is that they get no food, except what they bring with them, and that they are then supported entirely by the oil which is in their flesh. This inference is corroborated by the experiments of the late Sir Robert Christison, who analysed the flesh of a clean salmon caught when entering the River Tay from the sea, and also another salmon when descending the Tay to the sea, after having been in the river for about six months. The amount of fatty matter was in the latter only about one-sixteenth of what existed in the former.*

* See Appendix A (page 37) for the details of Sir Robert Christison's analysis; and also for some corroborative remarks by the late Frank Buckland. 
The young of the salmon, on their way down to the sea, are preyed on by many enemies. Sea-gulls and herons devour them in large quantities. When they reach the mouth of the river, there are millions of "podlies" (Merlangus carbonarius) watching for them. The Tweed Commissioners, to lessen the slaughter, employ boats and nets to catch these "podlies." The last return of which I have a note represents 6040 caught in May and June. Many of these creatures, when examined, were found with the remains of eight or ten smolts in their stomachs.

The migration of Tweed salmon has been to some extent investigated by the Commissioners. With the view of ascertaining the changes of size and shape in future stages of life, we for many years were in the practice of catching fish of all kinds, and putting a silver wire into the dorsal fin, with a special number stamped on it. When any of these wired fish were caught, the wire was sent to our Superintendent, with a description of the fish, by length and weight, and of the place where caught. In this way we had reported to us cases of Tweed salmon caught in the Firth of Forth, on the coast of Aberdeen, and in the rivers Don and Dee of that county. Along the coast of England to the south of the Tweed, we had cases reported to us from Holy Island, from the Tyne, from Shields, and even from Yarmouth. This last case, on account of the distance travelled, is especially interesting, the wire having been fastened to a bull-trout caught in the Whitadder, a tributary of the Tweed, on the 29th of March, I852, and the fish having been caught in a net at Winterton, near Yarmouth, on the 2nd of April; it had travelled, therefore, nearly 300 miles in four days. Another fish, marked in the Whitadder on Ioth March, I880, was caught at Yarmouth on 5th May, I880 (see Appendix B, page 38). 
When salmon are swimming in the river Tweed up stream, it has been estimated by experienced anglers that they travel at the rate of about two miles per hour.

Salmon, in descending the river after spawning, are generally emaciated and exhausted. Many, apparently hardly able to swim, float down the stream to the sea. Every spring, large numbers are found dead at the sides of the river, or in pools.

What causes the migration of salmon is matter of conjecture. I have observed, when walking along the Berwickshire coast, salmon leaping frequently at or near the mouths of small rivers or streams; and it has occurred to me that, as they must get into rivers for spawning, instinct induces them to seek those rivers the waters of which they find most suitable for the purpose.

Certain it is that salmon, after having frequented particular rivers from time immemorial, have abandoned them, and the inference is that they betake themselves to other rivers which they deem preferable.

As an example of this, I may refer to the river Whitadder, which has a course of about forty miles from the Lammermuir Hills. This river joins the Tweed, at a distance from its mouth of about three miles; so that all the salmon caught in the higher parts of the Tweed must have passed the mouth of the Whitadder. The tide flows into it, as well as into the Tweed, flowing up the latter, for six or seven miles. Formerly the true Salmo salar frequented the Whitadder; but during the last thirty years no salmon of that variety has been seen in it. It is frequented only by bull-trout.

Reference may also be made to the Thames and to the Coquet (Northumberland), both of which rivers used to be frequented by the true salmon. I might also quote the 
Esk in Mid-Lothian, where, about fifty ycars ago, I have scen hundreds of truc salmon wriggling up over the millweirs; but there have been no such fish in that river for the last twenty years.

Where have all the salmon and their progeny gone to, which frequented these rivers? The natural conclusion is, that rivers elsewhere have been resorted to.

In some of the cases I have mentioned, and in multitudes of others, the probable cause of desertion, was the pollution of the streams by the establishment of paper-mills, dye-works, mining operations, and other manufactures, the refuse of which rendered the waters in these rivers unsuitable for salmon life.

Thus, about thirty years ago, shortly after the establishment of paper and woollen works in the upper parts of the river Whitadder, I used to see its lower parts covered with an oily scum and foam most destructive to fish.

These remarks lead me to refer to other circumstances inimical to salmon when in our rivers.

One is the formation of mill-dams or weirs, of such heights that, except in "spates" or heavy floods, the fish cannot reach any spawning grounds. In the cases of the Thames and of the Coquet, the English Fishery Inspecturs, after careful investigation, gave it as their opinion that what originally caused desertion of salmon from both rivers, was the erection of impassable mill-clams and lockis, which cut off access to spawning grounds. On the other hand, there are rivers where salmon have become more plentiful, as in the Tyne; and the Chairman of the lishery Conservators of that river informed me, that he attribute this increase chicfly to the removal of mill-dams and the formation of fish-passes. It scems a well-established fact that unless the fish find suitable sround for spawnins 
they retain the ova and milt, causing great risk of fatal inflammation; and accordingly every winter, multitudes of fish, both male and female, are found dead and unspawned - in many cases with milt-sacs and ovaries diseased.*

I believe that the state into which our rivers get by excessive drought, is another cause of much unhealthiness to salmon. The rain falling on our agricultural districts rushes off at once through land drains; so that our rivers, instead of continuing in flood for a week or ten days, fall to their ordinary level in three or four days; and in dry weather, the fish congregate in pools, where the quantity of water is so small, that the supply of oxygen for respiration is insufficient.

A curious fact may be referred to, which perplexed the late Frank Buckland, viz., the entry of grilse into our rivers, at a season when it is probable they do not come for spawning. In the north of Scotland, they enter the rivers on the east coast, in January and February, but on

* Return by Mr. List, Superintendent of Tweed Water Bailiffs, of salmon, grilse, and bull-trout, found dead or dying in the river, which were taken out of the river and buried, distinguishing the spawned and the unspawned.

\begin{tabular}{|c|c|c|c|c|c|c|}
\hline & & & $\begin{array}{l}\text { Season } \\
1880 .\end{array}$ & $\begin{array}{l}\text { Season } \\
\mathbf{1 8 8 1 .}\end{array}$ & $\begin{array}{l}\text { Season } \\
\text { I } 88 z \text {. }\end{array}$ & $\begin{array}{r}\text { Season } \\
188_{3} .\end{array}$ \\
\hline Spawned . & .. & . & 4694 & 2542 & $1143^{8}$ & 3996 \\
\hline Unspawned & .. & - & 528 & 365 & 3189 & 864 \\
\hline
\end{tabular}

The late Frank Buckland, in his Igth Report, p. 34, says:-1 A question of considerable importance, bearing on the salmon disease, has arisen, viz., whether a female salmon has the power to withhold her eggs? Now, I know most positively that she has the power." 
the west coast, though on the same latitude, not till May or June. The explanation suscirested by Mr. Archibald Young, Fishery Inspector for Scotland, seems to me correct, founded on the relative temperatures of the sea and of those rivers. The sea on the west coast is from two to three degrees warmer than on the east coast. On the other hand, the rivers flowing eastward into the German Ocean, lose their winter temperature, before reaching the sea, more rapidly than the rivers flowing by a shorter course towards the west; because the snowclad mountains, from which both sets of rivers flow, are nearer the west coast than the east coast, and therefore the west-flowing rivers are, at their mouths, colder than the east-flowing rivers at their mouths. The fish may therefore seek to get out of the cold sea-water on the east coast, by at once entering the rivers flowing there into that sea; whereas on the west coast, the fish may incline to remain in the warmer sea-water there, until the temperature of the rivers has risen, after the snow has melted.

This solution of the problem, being one of a metcorological character, is now being tested by thermometers, which His Grace the Dule of Sutherland has kindly caused to be placed and observed in the Sutherlandshire rivers.

A question occurs on Tweedside, regarding the spawned and spent fish, called "kelts," which are often so emaciated, that the clause in our Act of Parliament forbidcling the capture of "foul, unclean, and unseasonable" fish, has been held to apply to them. Sometimes, however, these kelts become, before reaching the sea, so improved in condition, that they are considered wholesome as food, and, being improved in appearance, are, when taken in 
the nets, not restored to the river. The expediency of destroying the kelts has also been maintained, on the ground that they devour "parr" in large quantities. I incline to think this a mistake. The kelts generally go down to the sea in February and March, at which time the "parr," like the common "minnows," hide themselves in the muddy bottom or sides of the river, or under stones. A neighbour of mine, who kept a supply of minnows in a pond in his garden for many years, told me that they always, during the winter months, buried themselves in the mud. My gamekeeper, when in winter he wants "mimows" for trout fishing, tells me that he has to seek for them among tree roots and other rubbish along the banks, by means of a small net. This is also probably the case with "parr."

\section{FishERIES.}

Having offered these remarks in regard to Fish, I proceed to the second part of the programme, viz. Fisheries, which I presume refers to the persons who fish for salmon, and to the rules for controlling their modes of fishing.

In Scotland, as I believe is the case also in England and Ireland, the original right of fishing for salmon is in the Crown, the privilege being capable of being exercised only by those who can show a Crown charter.

Until about thirty ycars ago, the Crown rights in this matter seem, in Scotland at least, to have been little attended to.

About that time, steps were taken by the Department of Woods and Forests, to ascertain what proprietors who were fishing for salmon, could show Crown charters.

The investigation began in the south-east of Scotland, 
and I was called on among others. I was able to show a good prescriptive title for both river and sea fishings, but many of my neighbours were not so successful, and then, of course, the Crown officers, their right to the fishings having first been established or acknowledged, advertised the salmon fishings to be let to those who offered the highest rent-a preference, however, being given to riparian proprietors.

This investigation has been carried on along the east coast of Scotland, and I believe also the west coast.

At my suggestion a return was obtained from the Woods and Forests two ycars ago, of the amount of these Crown salmon fishings for the ycars cnding respectively Martinmas, $1 \& 7 \mathrm{I}$, and Martinmas, IS\&I, from which it appears that the sum drawn for Crown leases of salmon fishings in Scotland in the former year was $£ 3$ IgS Is. $2 d$, and in the last-mentioned year $£ 5$ IIO I4S.; this progressive increase arising from the additional fisheries taken possession of by the Crown officers.

The total amount of the rental received by all kinds of leases of salmon fisheries in Scotland, is believed to be about $£ 250,000$.

There are, however, no statistical returns which can bc relied on for accuracy on this point. The old Scotch Fishery Board (which was abolished last ycar by the Scotch Fishery Act) concerned itself only with sea fish. Since the new board was organised, there has been, as authorised by that Act, an inspector of Scotch salmon fislicries appointed by the Secretary of State for the IIome Department, who is entitled to seck information regarding the numbers and value of salmon caught, but who has only recently cntered on his duties. 
The regulations in Scotland for salmon fishings are, many of them, the same as in England.

(I) Thus there is an annual winter close time; which in Ireland continues for I68 days, in England for I 54 days, in Scotland for I7o days. In the open season of summer, there is a weekly close time; lasting in Ireland 48 hours, in England 42 hours, in Scotland 36 hours.

(2) No fixed nets are allowed in our rivers or in our estuaries near the river mouths; and no nets with meshes smaller than one and three-quarter inches, so as to avoid catching parr, smolts, or small river trouts.

(3) Pollution of rivers, to such an extent as to kill salmon in them, is nominally prohibited; but the clauses in all the Scotch Acts are so weakly worded, that I don't know of any case in Scotland, except one, where fishery proprictors or Fishery Boards have been able to enforce these prohibitions for the protection of fish.

No power was by these Acts even attempted to be given to prevent pollution. It is only after a fish has been killed by it, that action is allowed ; and even then it is exceedingly difficult, indeed, almost impossible, to show, that when a fish is found dead, it died from the effects of poison which came from any particular mill.

The Tweed Fishery Act has existed for 26 years, but it was only last year that a case occurred, where the Commissioners ventured to exercise their powers in this respect. Noxious matters were discharged from a mill, which killed every kind of fish in the river for two or three miles below the mill. There was a general outcry at such an outrage. A leading Edinburgh angling club cndeavoured to prosecute, but was baffled by a technical defect in the wording of the Scotch Freshwater Fisheries Act. The Tweed Salmon Commissioners, however, called on the county Pro- 
curator Fiscal (who is the local Public. Prosecutor in Scotland) to institute procecdings in respect of the destruction of thousands of Salmonidax, which gave to the Tweed Commissioners a right of action. The County Sheriff awarded a sum of $£ 2$, being the full allowable penalty. The party convicted appealed to the Supreme Court in Edinburgh. There, the Sheriff's judgment was affirmed, with an award of $£ \mathrm{I} 2$ of expenses; but it cost the Tweed Commissioners $£ \mathrm{I} 57$ to obtain the conviction! - a proof of the utter insufficiency of the existing law to meet even a case so manifestly flagrant as that just referred to.

This subject of river pollution suggests a remark of wider application. Important as it is to afford to Fishery Boards more legal power for the protection of fish, the gross pollution of our rivers, streams, and lakes by sewage and manufacturing refuse, ought to be prevented for the sake also of higher interests. The health and domestic comforts of thousands of our population demand, that there be a stringent law declaring such pollution to be a crime, irrespective of any proof of injury to fish or to individual riparian proprictors. A public officer ought to be appointed, not only to prosecute such offences when they occur, but to prevent the discharge of noxious matters (whether from towns or private houses), and even the erection on the banks of rivers of any manufacturing works, which would cause gross pollution of the water.

(4) Another point of importance, as regards Scotch salmon fisheries, is the mode of enforcing the prescribed rules of fishing.

On the Tweed we have no difficulty with the lessees of the fishings, or the men employed in working the nets, who are about 476 in number. But we have great difficulty in repressing the poaching which goes on cluring the 
long nights of the annual close time (extending for nets from September I4th to February I5th), especially in the upper reaches of the river, where spawning beds are situated. In these districts, there is a dense manufacturing population, in and near the towns of Hawick, Jedburgh, Galashicls, Selkirk, Inncrleithen, and Peebles; and the mill-workers greatly enjoy the recreation of going out in parties at night, with torches, to capture, by means of rake hooks and hand nets, salmon in the shallow streams.

On an average of the last two years, the number of poachers detected and convicted at the instance of the Tweed Commissioners was $22 \mathrm{I}$ in the year; the cost of prosecuting them was $£ 266$, and the amount of fines and expenses awarded to the Commissioners was about $£$ I 49 .

The number of our Water Bailiffs or River Watchers has been, on an average of the last two years, 49 during the six months of close time, and 13 during the rest of the year.

In order to pay the wages of bailiffs, the cost of prosecutions, and the salaries of managing officials, the Tweed Commissioners are entitled, under their Act of 1857 , to assess themselves, and the other proprictors of fishings, to the extent of 20 per cent. on the rentals or values of the fishings. These amount at present to about $£ \mathrm{I} 3,000$ yearly, so that by assessment we have about $£ 2,500$ at our command for protection and management.

If, however, the terrible fish epidemic, which for the last two or three years has affected the Tweed, continues, we must expect our income from fishing rents to fall, not only because of the decrease in the number of fish, but because of the disinclination of sportsmen to frequent our river for angling, the enjoyment of which is undoubtedly lessened by the ghastly sight of diseased fish. 
As the salmon discase has already becn a subject for separate discussion at these Conference mectings, I abstain from any remarks on it, beyond mentioning that during the last three years, our bailiffs have drawn out of the Tweed and its tributarics, altogether 27,100 salmon, grilse, and bull-trout, either dead or dying, in order to bury them. The value of these, at an average weight of 7 lbs. cach, and an average price of $\mathrm{I} s$. per pound, amounts to about $£ 20,000$ sterling.

(5) The Commissioners who manage the Tiveed fisherics, are all persons whose income from fishings excecds $£ 30$ yearly, or who possess a river frontage of half a mile. They form a numerous body, and hold a meeting once a year, when they appoint a Committee of Management, consisting of twelve of their own number, resident on or near the river, and known to take an interest in fishery matters. His Grace the Duke of Roxburghe is Chairman of the Committee.

In other parts of Scotland, the management of the salmon fisheries is, or rather ought to be, in District Fishery Boards, which were appointed to be constituted by two Acts passed in the years I862 and IS68. But the proprictors of salmon fishings so much disliked the constitution of these Boards, that when the sheriffs of counties summoned them to meet, to elect Boards for the different districts, very few proprieters responded to the call. Scotland had been, by three Government Commissioners, previously divided into 105 districts, each comprising one or more salmon rivers; but the result was that no more than 30 Boards were formed, and during the succeding ten years, eight of these Boards ceased to meet, so that there are now altogether not more than 22 Boards in existence. To show the present state of things, I may quote the [2I] 
following from a report of the Scotch Fisheries Improvement Association, read and adopted at the public annual Meeting held at Edinburgh in May I88 I :-

"There are seven counties in Scotland, with 32 rivers, which have ceased to be frequented by salmon; owing, first, to dams built across the rivers, which prevent the fish getting up to spawn; and, second, to manifold pollutions from town sewage, bleach-fields, chemical works, and other manufactories.

"In eight counties with salmon rivers in them, there are no District Fishery Boards.

"In one of these counties, viz., Ross and Cromarty, there are no less than 32 salmon rivers, all without official protection.

"In Argyleshire, where there are about 30 salmon rivers, there is but one District Fishery Board, and its place of meeting (when it does meet) is in the Island of Mull."

There has thus been almost an entire collapse of the arrangements which were devised by Government, and sanctioned by the Legislature in IS68, for the protection and management of the Scotch salmon fisheries.

In the year IS70, this fact became known to Government, through the reports officially made by the different county sheriffs, who had been appointed by the Act of Parliament to take steps for forming the District Boards. I must do the Government of that day the justice to say, that viewing the matter in a serious light, they lost no time in endeavouring to obtain the best information with a vicw to a remedy. The Honourable Mr. Bruce (now Lord Aberdare) then Secretary of State for the Home Department, appointed two competent Commissioners, the late Frank Buckland and Mr. Archibald Young of Edinburgh, to visit the different counties in Scotland, and report, "how far District Fishery Boards are in operation in Scotland, 
and whether any alteration in their constitution is desirable." The Commissioners at once proceeded with the inquiry, and made a report stating that, to procure the necessary information, they had visited the principal salmon rivers in Scotland (forty-six in number), and had personal meetings with twenty-two District Boards, and also with many landed proprietors interested in the fisherics. They further reported, that whilst the total number of fishery districts which had been designated by the $\Lambda$ ct of Parliament to be managed, each by a separate board, was 105, yet "at this moment (viz., in IS7I) there are not above 30 District Boards constituted and working."

The Commissioners also reported that the constitution of the burrds was unsatisfactory, and they suggested some modifications, though apparently without much confidence in their likelihood of success.

Shortly afterwards, there was a change of Government, which may, perhaps, have been one reason why no steps were then taken to remedy a state of things so injurious to a great national industry which supplies a large amount of much prized food, and gives employment to about from I 4,000 to I 5,000 of the population in Scotland.

What has been the consequence of matters having been allowed to remain in the nearly total absence of any proper authorities for enforcing the law? Over two-thirds of the country, both in our rivers and alones our sea-coasts, poaching in annual and weekly close times, - capturing of salmon fry,--river pollution,-obstructions in rivers, and illegal netting, have been prevailing, without check or hindrance.

If asked for evidence of this, I refer to the testimony of Mr. Young, who knows more about our salmon fishings than any one else, and who in the ycar 1877 published a pamphlet, in which he states as follows: "Poaching 
is universal along the coast of Argyle, and among the islands; the central point being the town of Oban, where thousands of sea trout are annually caught by persons who have not a shadow of right to fish for them, and which are openly sold without any interference." *

Then, turning to the east coast of Scotland, I refer to the testimony of Mr. A. B. Hogarth, Aberdecn, who at a public meeting of fishery proprictors, held last April in Edinburgh, voluntarily came forward to support a resolution affirming that salmon in Scotland were decreasing in number, and stated, "that the amount of over-netting which had taken place on the sea-coasts during the last ten years, was something past all comprehension. He added, that he had been a fisherman for thirty-five or thirty-six years; but it was only within the past ten years, that things had gone on to such an extent." This testimony is all the more reliable, being given by a tenant of extensive coast fisherics, who had been carrying on, without objection or interruption, a practice admitted to be alike injurious and illegal.

These local testimonies from Scotland are confirmed by the returns from Billingsgate market, where an accurate record has long been kept and published of the numbers of salmon received there from England, Ireland, Scotland, and other countries. Taking the returns of the last ten years, and comparing the average number of salmon brought there, during the last five ycars, with the average number brought during the first five years, I find there has been during the last five years an increase from England of 20 per cent., and from Ireland an increase of $2 \frac{1}{2}$ per cent, but from Scotland a decrease of 20 per cent.

* 'British Industries,' p. 287 (Stanford, Charing Cross, I877). 
There being a gencral conviction in Scotland of the decline of our salmon fisheries, and no appearance of any intention on the part of the Executive Government to adopt remedial measures, a number of fishcry proprictors and representatives of angling clubs, conceived the idea of forming an Association for endeavouring to make the Scotch public aware of the virtual non-existence of any proper system of protection and management of the fisheries, and also to urge upon Government the necessity of better legislative arrangements.

At a public mecting in Limburgh, held in January ISS I, the Scotch Fisheries Improvement Association was established with that view. His Grace the Duke of Sutherland consented to be President; and the Earl of Breadalbane, the Earl of Dalhousie, Lord Polwarth, the late Sir Robert Christison, Sir James M. Gibson, and myself were appointed Vice-Presidents; with a Council of fifteen members, practically acquainted with the subject of salmon fisheries.

This Association has accordingly, by means of public meetings for discussion, by circulation of Reports, and by sending memorials and deputations to Government, endeavoured to make known and urge the necessity of remedial measures.

I also individually endeavoured to contribute some amount of help towards the same object, by the publication of a small tract, to explain the reason why the District Fishery Boards authorised by the Acts of IS62 and IS6S were so much disapproved of in Scotland.*

I there ventured to suggest that the lines of the

* In Appendix C., p. 42, extracts from this tract are given by the courteous permission of the Executive Committee of this Exhibition 
English system of River Conscrvators (as they are termed) might be followed in Scotland. The English Boards consist of two classes of members, proprictors and lessees of fisheries. The proprictors are selected by Quarter Sessions, the number on the board for each district being previously fixed by the Secretary of State for the Home Department; and to these selected members, there are added a certain number of ex officio proprietors, having a rental from fisheries exceeding $£ 30$. The other class of persons on the English Boards, are lessees of fishings, and consist of persons holding licences to fish; for in England (and in Ireland also) it is the law, that persons wishing the privilege of fishing, whether by net, rod, or boat, must take out licences, and pay for them certain dues to be approved of by the Home Secretary. These licence dues form a fund, which is at the disposal of the River Conservators.

It will be observed from this explanation, that only a small number of the members on the English Boards are members ex officio. The majority are selected, on account of their qualifications for the duty, by others who are supposed capable of judging of these qualifications.

Now what is the constitution of the Scotch Boards, as explained in the Salmon Act of I 862 ?

All the Boards consist of the same number of members, whatever be the size of the district; viz., three fishery proprietors from the lower parts of a river, and three from the upper parts. If there be in either of these districts, only two fishery proprietors, then, whatever be the number of proprietors in the other district, the total number on the Board must be four. And if in one of the parts of the river there is only one fishery proprictor, then the total number can only be two members 
besides the Chaiman. IVith regard to a Chairman, he is not elected by the members of the Board, as is usually the case. The Act appoints the proprictor of largest fishery rental in the district to be Chairman, without reference to his haring any other qualification; and he has both a deliberative and a casting vote.

The result of such an arrangement was to throw the whole power of the Board into the hands of the lower proprictors, inasmuch as the Chairman, on account of his high rental qualification, is almost always connected with the lower part of the river.

The consequence is, that the upper proprietors, seeing that they have no influence in clirecting the action of the Board, decline in most districts to become members, or at all events to attend the Board meetings.

Another objection to the Boards is the expense to which nembers would be subjected, by having to assess themselves and other fishery proprietors, to defray the costs of prosecutions, to pay the wages of water-bailiffs, and to pay the salaries of officials, - the Act declaring that all these expenses fall on the Boards; and in many districts, the fishery rents are not sufficient to meet these expenses.

It was likewise felt to be an invidious and odious duty to throw on proprictors the institution of prosecutions for the imposition of fines and imprisonment.

Another serious difficulty which militates against the practicability of these Boards, is the scanty number of resident proprietors in many of the northern and midland counties of Scotland, and the great distance of their dwellings from one another, rendering attendance at meetings almost impossible.

These being some of the objections to the proposed 
Boards, and which, as already mentioned, prevented the formation of no more than about 20 , out of the 105 required, the practical question now is, what can be thought of, as likely to succeed in place of these Boards?

The chief suggestion made in the Report of the Commissioners appointed by Lord Aberdare was, that where in any district a Board has not been constituted, a Fishery Inspector, nominated by the Secretary of State for the Home Department, should exercise all the powers of a Board.

I failed to see how this plan would work. The arrangement which I suggested, and which I may now bricfly sketch, was as follows :-

Ist. To allow no persons to fish for salmon in Scotland, without taking out a Licence-the amount of the dues to be fixed by the Secretary of State for the Home Department.

2nd. To have in districts embracing one or more salmon rivers, a Board, consisting, as in England, partly of proprietors and partly of lessees of salmon fishings; the proprietors who are to be members of the Board, to be selected by a committce, consisting in each county, of the Lord Lieutenant, the Convenor of the County, and the Sheriff; - the lessees of fishings who are to be members of the Board, to be selected at a meeting of persons holding Licences, called publicly by the Sheriff; and the Chairman to be elected by the Board-either from among their own number or otherwise-the election being yearly.

3rd. With regard to expenses, these are of three classes: Ist, salaries of officials to assist in the management; 2nd, wages of water bailiffs; and $3 \mathrm{rd}$, cost of prosecutions.

The first two classes of expenses would be defrayed 
out of the funds to be raised by licence dues; - a plan which I have reason to believe would mect with the support of the Tweed Commissioners.

The last class of expenses should, I think, fall on the officials who in Scotland are now and have always been entrusted with the administration of the criminal law. Looking to the severity of the punishment for offences authorised by the Salmon Acts, consisting of fincs reachines up to $£ 20$, and of various terms of imprisonment up to six months, it scems to me unconstitutional, incxpedient, and anomalous, to give to Boards the power, and still more to impose on them the duty, of acting as prosecutors. In cases of an analogous nature, such as night poaching; killine game in close time, fishing for oysters, lobsters, and mussels in close time, the prosecutions are, and can only be, at the instance of the Procurator Fiscal,-an official who is subject to control, and even to dismissal, for any impropriety or mismanagement. The expenses of such prosecutions are audited by the county magistrates, and, if found correct, paid out of the county funds. Why should the same rule not be followed in regard to offences under the Salmon Acts?

What is the practice in England in regard to the prosecution of offenders under the Iishery Acts, I do not know.

In Ireland, offences against the fishery laws are taken notice of by the county constabulary, and prosecutions are conducted by them, as well as by Fishery Conservators.

I have now related, I fear at too great a length, what we have been doing or trying to do in Scotland to bring about some amendment in our salmon fishery laws. During last year, a Fishery Act was passed for Scotland, abolishing the old, and creating a new fishery board, which has been so far a step in the right direction, that 
it includes among the powers of the Board a right to take cognizance of salmon, for the purpose of collecting information of a statistical nature.

The Act, however, gives no power to the new Board to make any change in the law bearing on the constitution of the Fishery Boards. But in the reports which the Board is to make annually to the Home Secretary, suggestions may be offered for the regulation and improvement of the fisheries-i.e., sea as well as salmon fisheries; and it is to be earnestly hoped, that this power will be promptly exercised.

What Scotland wishes and requires for salmon protection, is to be put on the same footing as England, where, -as Mr. Spencer Walpole says in his Report of IS79 on the English salmon fisheries, "Every river in England capable of producing salmon, is now under the protection of a Board of Conservators."

Many of my countrymen think, and I confess I share the opinion, that we in Scotland are too far off to be heard by the Executive Government. Therefore I am glad of the opportunity of opening my lips on this subject at the present influential Conference, trusting that what has now been spoken by me, however fecbly, may reach the ears of those who have power to provide a remedy.

In conclusion, may I express a hope that this Exhibition will strengthen the appeal which we Scotchmen have been making, for the better protection of our freshwater fish, by the evidence it affords of what other nations are doing in that respect, especially Canada and the United States. Let us not be ashamed to confess past indifference on the subject, but take a lesson from others, to enable us to fulfil a duty laid on us alike by the gifts of Providence, and by a regard to the interests of the country. 


\section{DISCUSSION.}

Professor Brown GoOdE (United States Commissioner) said he had listened with very great interest to the Paper which Mr. Milne Home had presented, and he rose to say a few words, which were perhaps invited by the closing sentences of the address, concerning what America had been doing in the way of salmon culture. He was led to do that by the fact that certain documents had been distributed from Canada, which had rather a tendency to depreciate what had been done in fish culture, not only in Europe, but in the United States. It had been saicl that fish culture was only an experiment, and had not been attended with commercial success: he, however, wished to say that it was in no sense an experiment, but that in the United States and in Canada it had been a decided success, and was so recognised by every one. It was not likely that the American Congress, or the Canadian Government, would for a period of ten or twelve years keep on making annual appropriations for fish culture if they were not satisfied that it was not only a success from a scientific stand-point, but a success from a commercial point of view. In the United States the general Government had appropriated considerably more than a million dollars, and the individual States a sum almost as great. Up to I79s large numbers of salmon were caught in the Connecticut river, but until 1870 the fish disappeared entirely from the river, and until about $1 S 75$ no salmon whatever were seen in the river. In 1875 , however, the salmon began to appear, and this was the direct result of the planting of a large number of eggs in that river three or four years previously. Then again in the case of Sacramento River 
of California, where about two million young fish werc planted ycarly, the catch had increased in five years from five million pounds to fifteen million pounds, and in I88 I there were more fish than could be utilised by all the canning establishments on the river. He would not procecd with the multiplication of examples, but would refer to the fact that the fish in the Detroit River, where the United States and Canada had established hatcheries, had becn increased, and the supply immensely improved. The shad was taken in twenty or thirty great rivers on the Atlantic coast, and was for several months of the year a most important food supply. About twenty years aģo it was found that the supply of shad was beginning to decrease, and Fish Commissioners were organised with the special object of increasing the supply. He had seen shad which four or five years before were selling at 4 s. or 5 s. a pair, and were therefore beyond the reach of poor people, become so cheap and common that they could be bought for a shilling a pair, which was entirely the result of fish culture. Professor Baird had been the leading spirit of fish culture in America. He was asked recently if Professor Baird was not an enthusiast, and he replied that he was not, but a man possessing the widest general and philosophical knowledge of natural laws, whose sound judgment and experience had enabled him to take up the work of fish culture and carry it on on an immense scale in the United States. People were sometimes dissatisfied because fish were sometimes planted in streams and nothing was heard of them afterwards; but it was the theory of their Commission and of their Government that it was a proper thing to make experiments, and if they happened to be unsuccessful there was so much ground eliminated over which it was un- 
necessary to go again. He thought the experiments which had been successful ought to be allowed to balance those which had not. Experiments in fish culture in Europe, especially in Holland and Germany, had yielded exceedingly promising results. Mr. Whitcher had singled out two rivers in Canada, out of many, for the purpose of supporting his view that fish culture had not been a success, and had stated that although a large quantity of salmon was taken out of certain waters in 187 I there was none in ISSI. Mr. Whitcher, as Commissioner of Canada, was charged with the preparation of a report to the Canadian Government upon the state of the fisheries. The report for I882, which surely ought to have been within Mr. Whitcher's access when he published the circular, stated that the salmon fisheries nearly all over Canada, had been much better in 1882 than within the preceding ten years; and other testimony showed that there had been a magnificent improvement. He knew that Mr. Wilmot, who had been criticised somewhat in the circular, would feel some diffidence in speaking on the point, but he thought he owed it to him to point out that the official documents proved that fish culture had not been in any sense a failure, but a decided success.

Mr. Wilmot (Canadian Commissioner) said it was with considerable diffidence that he rose to make any remarks upon that important question. He had been much delighted by the very instructive paper on salmon fisheries, a subject which of course required a great deal of time to enter into fully. Mr. Milne Home, on the opening of the Exhibition, visited the Canadian Court, and he felt sure, from the way in which he expressed his views, that he was extremely delighted with the modus operandi of fish culture in Canada. A few days ago Mr. Home called upon 
him, and stated that he was somewhat astonished to sec from a circular he had received from one of the officials in Canada that fish culture had been seriously found fault with, at the same time stating that as he was about to read a paper on salmon fisheries, it would be his duty to refer to the subject, as it was of great importance, and affected very seriously the interest of the salmon fisheries throughout the world. He was pleased that Mr. Home had not done so, as it gave him the opportunity of going into the matter very fully; but as it appeared that many other persons had received circulars of the same kind, he felt, on behalf of that great and important portion of the British Empire, Canada, whose govermment had thought proper to expend large sums of money in advancing the interests of salmon culture, he ought to say a few words on the point. Salmon culture was initiated in Canada by himself as a private individual, and he was pleased to say that from the day it was initiated it had gone on progressing and prospering. The Government of Canada at first thought very little of it, but looked upon it as one of those things which required further development before they could grant aid. In $x \$ 68$ there was a small grant of $£ 40$, but the annual grants now amounted to some $\$ 30,000$ a year, which showed what importance the Government now attached to salmon culture. The salmon fisheries of the world required the utmost protection, and care must be taken to prevent fish being destroyed during the breeding seasons. Salmon culture ought to be carried out in every country where those fish were indigenous to the waters. In Canada fish culture had been carried on for a length of time, and its fruits were beyond cavil. There were, however, some people who found fault with everything, no matter what it might be, 
and he regretted very much that Mr. Whitcher, a colleague of his in the Canadian Fisheries, should have thought proper to issue circulars amongst the Commissioncrs, stating that fish culture had not been satisfactory. Mr. Whitcher's own documents, evidently not written nor read by himself, however, proved the very reverse of that statement, and the blue-books of Canada contained returns which showed most conclusively the beneficial results arising from the protection of rivers and the raising of salmon by artificial means. After quoting a number of returns from Inspectors of Fisheries and other officers from the annual reports of I882, proving that there had been a very remarkable improvement in the salmon fisheries of Canada, he said it would be quite unnecessary to read the individual reports of fishery officers in all parts of Canada, which, with only a few exceptions, indicated that the salmon were increasing wonderfully during I $8 S 2$. He might also mention that he had received letters stating that the catch of salmon by netters and anglers in $I_{8} 83$ had been in excess of any previous period, especially in those rivers where salmon hatcheries were in operation. It was the duty of all civilised governments and intelligent people to adopt such means as would bring about a better supply of food, and he had no hesitation whatever in saying that the means adopted in Canada had in most instances been very beneficial. Perhaps on some future occasion the matter might come on again; if so he could give volumes of even stronger evidence in proof of the success attending fish culture.

It was painful indeed to be obliged at this Conference to refer to the circular issued by this well-known official crank in Canada, who, to gratify personal spleen, had wantonly attacked an industry of world-wide beneficial 
reputation; more especially as the Canadian Minister at the head of the Fisheries Department, and himself, were here on behalf of that country advocating the importance of fish-cultural operations in the Dominion, the practical display of which, at this great International Fisheries Exhibition, had gained for itself great popular favour, and also materially aided in the general exhibit, and placed Canada amongst the foremost of the nations for cfficiency and completeness in the science of artificially propagating fish. From the gratifying way in which Professor Goode's remarks and his own had been received on this subject, it was clearly unnecessary to refer further to this "under the belt" stab in the circular, feeling assured that similar conduct is always frowned down by the manly English public.

Mr. C. E. Fryer (Home Office) said if the Exhibition fulfilled no other object than that of making pcople think, it would have achieved a great work. They had just received a great deal of information about the manner in which fish culture was carried on in the United States and in Canada, and as to the beneficial results derived from the artificial culture of salmon, and he would just say a few words to show the benefits which had resulted from the protection of salmon in this country even without artificial hatching. In 1863 the value of the salmon rivers in England and Wales was about $£ \mathrm{I} \$, 000$; at the present time the value of the same rivers was somewhere about $£$ I50,000. That increase, large as it was, by no means represented the possibilities of English rivers, if they were purified and greater facilities given for the access of saimon into the upper waters to spawn. This had already been done to a certain extent; and, in addition, restrictions had been placed on the power of man to catch the salmon in 
the mouths of the rivers, and to destroy them when they were on the spawning beds: and to those two things alone was due the large increase which had taken place. $\mathrm{He}$ did not for a moment wish to depreciate the value of the efforts made by fish culturists in Canada and the United States, but he thought before they went very largely into salmon hatching in England they must do a great deal more to make the rivers fitter to receive the fish to be put into them, by removing pollutions. Means should also be adopted to enable the salmon to pass at their own free will up and beyond the dams which cut them off from the spawning beds. Mr. Milne Home had referred to the question of pollutions, and he would take that opportunity of congratulating him upon the result of an action which had been tried at the Court of Session, the result of which would be that one of the tributaries of the Tweed would be freed from its pollutions. The artificial culture of fish had been of cnormous advantage in stocking waters with fish, which those waters had never contained before; but he thought that by purifying the rivers, by placing ladders which would enable the fish to surmount the weirs, by protecting the fry of the fish in the upper waters, and in the lower waters by preventing the fishermen entirely blocking the mouths of the rivers by enormous nets, they would be able to greatly improve the salmon fisheries; and then artificial culture might come in. If they took the pollutions out of the Thames, and put ladders up the weirs, they might bring back the day when twenty or thirty salmon used to be caught at a haul, and when salmon used to sport themselves opposite the home of the Legislature at St. Stephen's. He hoped the Legislature would take heart of grace, and insist upon the pollutions being removed from the Thames and other 
rivers, and then they might sec, not only salmon, but fish of other kinds greatly increased.

Mr. JAS. H. Crossman, in proposing a vote of thanks to Mr. Milne Home for his very valuable Paper, said that one of the beneficial results of the Conferences was that gentlemen of experience from all parts of the world were brought together to discuss these interesting questions. He had always been of opinion that if the regulations governing the Tweed fisheries could be applied to the other rivers of Scotland they would not have to complain of the falling off in the Scotch salmon fisheries. As a member of the Executive, he might plead as some excuse to $\mathrm{Mr}$. Milne Home for the audience not being larger, that there had just been another important lecture on "Fish as Food," by Sir Henry Thompson; but the able paper which had been brought before them would be printed and distributed, and would therefore not be lost sight of, but be thoroughly well considered.

Mr. BLoomfield seconded the vote of thanks, and said that he, as an Irishman, had felt some pleasure in finding that Scotchmen were not always able to do things as well as an Irishman. As an old magistrate of thirty years' standing he linew something of the matter, and he could say that they were in a much better position in Ireland than they appeared to be in Scotland, from what Mr. Milne Home had stated. The representatives of Canada and the United States had, he thought, given them some hints which were worthy of consideration. They had shown what the younger Governments were doing to further the interests of the people by increasing the supply of fish; and he was afraid the old country was very much behind them. Fish was an important article of food for the 
people, and as such should be protected and looked to by the Government. He would ask the Home Office to reconsicler the matter, and not only because they had not taken the pollutions out of different rivers, but because they have failed in their duty by neglecting to propagate the fish in the rivers that were to receive them. He hoped that what had been said would not pass out of their minds, but would remain there until they had induced the Government to do their duty in the matter.

Mr. Milne Home, in reply, said that if there had been nothing more than the opportunity which had been given to his friencls from the United States and from Canada to give the explanations to which the meeting had been listening, the Conference had done good. He had been somewhat astonished when he read the circular referred to, because it was in contradiction to what he had read of the complete success of artificial fish culture, and he could not believe it possible that such statements were correct, but he felt it was not for him to bring the matter forward in a paper relating only to the fisheries of this country. They had had the pleasure of hearing from Mr. Wilmot and Professor Brown Goode that the statements were not to be credited, and he cordially agrecd with the views which had been expressed as to the value of artificial hatching. They had in their own country a hatchery belonging to his friend Mr. James Maitland, which he had visited twice, and knew to be a success. There was one in Dumfriesshire, and there were two or three others, on a smaller scale. He hoped they would soon have more of those private establishments, but he also could not help thinking and saying that there ought to be some encouragement given to them by Government. If they were to appoint an inspector to visit those esta- 
blishments and report upon them, with a view to make known what they were doing, it would be a good thing. He had for some years past endeavoured to possess himself of the Reports of the Canadian and United States Commissioners, and had obtained from them very valuable information; and he thought we in this country ought to learn a lesson from Canada and the United States.

Mr. Milne Home then proposed a vote of thanks to the Chairman, which was carried unanimously.

The Chairman, in response, thought the pith of what had been said was, that they should all use their best endeavours to induce Government to assist in the propagation of fish and in the increase of the number of salmon in this country. Out of evil often came some little good, and he thought the circulation of the documents which had been referred to, instead of doing harm, had brought out more clearly the great success which had attended the artificial propagation of fish. 


\section{APPENDIX A (see page 6).}

Sir Rober'T Christison's conclusions were founded on the examination of a salmon entering the River Tay from the sea weighing $20 \mathrm{lbs}$, and of a kelt weighing $27 \mathrm{lbs}$., taken in a tributary of that river from a pool, where spawned fish were known to congregate, on their way back to the sea.

Sir Robert says that "the clean salmon presented abundance of fat under the skin, and in masses between the muscles." The kelt, "a male fish, was lank in the belly, and soft in the flesh." "I subjected it to analysis in the same way as the clean fish. I cut one piece of muscle from the dorsal region a little in front of the dorsal fin, and another from the ventral region directly opposite; so that the one should represent the thick and the other the thin of a slice of salmon."

"Four hundred grains of each were cut into fine chips," and then subjected to a chemical treatment, which he describes. The following elements were obtained:-

\begin{tabular}{|c|c|c|c|c|c|}
\hline & - & & Dorsal. & Abdominal. & Mean. \\
\hline \multirow[t]{2}{*}{ Salmon } & $\left\{\begin{array}{l}\text { Oil } \\
\text { Fibrine, albumen, \&c. } \\
\text { Saline matters and water }\end{array}\right.$ & & $\begin{array}{l}16 \cdot 66 \\
20 \cdot 57 \\
62 \cdot 77\end{array}$ & $\begin{array}{l}20 \cdot 40 \\
18 \cdot 82 \\
60 \cdot 78\end{array}$ & $\begin{array}{l}18 \cdot 53 \\
19 \cdot 70 \\
61 \cdot 77\end{array}$ \\
\hline & & & $100^{\circ} 00$ & $100^{\circ} 00$ & $100^{\circ} 00$ \\
\hline \multirow[t]{2}{*}{ Kelt . } & $\left\{\begin{array}{l}\text { Oil } \\
\text { Fibrine, albumen, sce. } \\
\text { Saline matters and water }\end{array}\right.$ & $\dot{*}$ & $\begin{aligned} r \cdot 20 \\
16 \cdot 92 \\
8 I \cdot 88\end{aligned}$ & $\begin{aligned} I \cdot 30 \\
17 \cdot 22 \\
81 \cdot 48\end{aligned}$ & $\begin{aligned} I \cdot 25 \\
I 7 \cdot 07 \\
8 I \cdot 6 S\end{aligned}$ \\
\hline & & & $100^{\circ} \infty$ & $100^{\circ} 00$ & $100^{\circ} 00$ \\
\hline
\end{tabular}

On these results Sir Robert remarks, that "the nitrogenous solids of the clean salmon, and its fat or oil, constituted together in round numbers $3^{S}$ per cent. of its flesh; - that there is decidedly more fat in the thin or dorsal region; - that there is very little difference in constitution between the dorsal and 
abdominal regions of a kelt; - that the kelt is a much more watery fish than a clean salmon; and that this is slightly owing to a deficiency in nitrogenous ingredients, but much more to an enormous deficiency of oil or fat, which is reduced to almost a sixteenth of the amount in a clean run fish." (Proccedings of Royal Society of Edinburgh for Session I 87 I-72, page 695.)

I find that the opinion expressed by me regarding the food of salmon when in rivers, was entertained by the late Frank Buckland. In his I 1 th Report, p. I 8 , he says that in the salmon, "there are no less than fifty pyloric appendages. Upon these I found firmly adherent a dense mass of white fat. In my report for 1868 , I promulgated the idea that one of the principal uses of the pyloric appendages was not only to secrete a fluid which assists in digestion, but also to act as a dipository of fit. This fat is derived from the food which the salmon eats when in salt water. It is stored up in a layer underneath the skin, as well as upon the pyloric appendages. During the stay of the fish in fresh acater, this fat is gradually absurbed, and its principal use is to go towards the formation of the milt and ova. In a fish running up from the sea, therefore, we find that the milt and ova are very small, while the fat on the pylorus is often so abundant as to almost obscure them from view." Again, at page 20 of the same report, Buckland says, "I do not think salmon eat much in fresh water. They subsist principally, as I have shown at page I8, on a store-house of fat which is laid up in their pyloric appendages. Nevertheless they take worms. In the Trent and in the Rhine the worm is a favourite bait, especially at flood-time. The food of the salmon, therefore, consists of herrings, sprats, smelts, sand-eels, fry of fish, and lugworms."

\section{APPENDIX B (see page 7).}

Wiтн reference to the cases of Tweed salmon caught in $185_{2}$ near Yarmouth, it may be noticed that the late Frank Buckland, in his Fishery Report for $1 S_{7} 6$, mentions the surprise with which he had learnt, "that every year large numbers of bull trout are 
caught in the neighbourhood of Yarmouth," there being no rivers in that part of England frequented by Salmonide. He says, "the fishermen begin to take these trout in the middle of April, and go on catching them to the latter part of July. The fishermen catch them near the shore from 30 to 130 yards from the beach. These trout exist in more or less abundance along the whole coast of Norfolk. They are migrating southwards. Their object, without doubt, is food, especially sand-eels and the fry of sea-fish, which are in abundance on the sands of the coast of Norfolk. These bull-trout must come from rivers flowing into the German Ocean to the north of Yarmouth." He then enumerates these rivers, including the Tweed, and adds that he had "come to the conclusion that the bull-trout caught on the Norfolk coast, are bred in one or other of these rivers." (Report, p. I6.)

That salmon migrate enormous distances is established by a fact communicated to the Tweed Commissioners by 1)r. Gïnther of the British Museum, that he knew " of an instance of a French sea-trout (now in the British Museum) leing caught in the Bristol Channel." ('Salmonoids of the Tweed,' Blackwood, Edinburgh, I 867 , p. IоO.)

In reference to two questions in my lecture, viz., the migration of salmon, and the deterioration of salmon in condition, whilst remaining long in fresh water, I here add some tables and notes taken from the Tweed Salmon Reports published by Blackwood, and also from some more recent reports by the River Superintendent, not published, but communicated to the Tweed Commissioners from time to time.

These extracts also give definite information regarding the position in the scale of fish-life, of the "orange-fins," "parr," and "black-tails."

\section{Eatracts from Reports made to the River Tweed Commissioncrs by their Experimental Committec.}

I. Young fish, considered to be orange-fins, about 100 in number, were put into a pond at Carham, belonging to the late Richard Hodgson Huniley, Esq., in May, I874, and were detained in it for five years, fed with bullock's liver.

These fish were from time to time examined by the Committee, 
and in their presence were weighed and measured by Mr. List, Superintendent of Water Bailiffs.

In February, 1877 , a number of small fry made their appearance in the pond, which were assumed to have been hatched there, from the ova of the detained fish.

MIr. J. B. Stirling, of the Edinburgh University, the assistant of Mr. Turner, Professor of Anatomy, and who had studied freshwater fish scientifically, having, on the invitation of the Committee, visited Carham and examined the fish, drew out the following Report:-

"Assuming that the fish, or some of them, put into the pond in May, 1874 , were orange-fins, they became black-tails in May, 1875 ; they became bull-trout in November, 1876 , and some of them would spawn about this time.

"The progeny would be hatched about February, I877, and would become parr in May, I877, and orange-fins in April, I878."

2. 'The result of the measurements of 80 fish in Carham

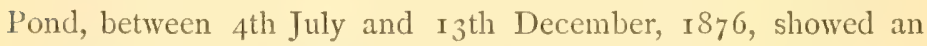
average increase in length of three-quarters of an inch. The measurements of 78 fish between $13^{\text {th }}$ December, I876, and 17 th May, 1877 , showed an average increase in length of only one-tenth of an inch.

3. Into a deserted, stone quarry, near Coldstream, filled with rain-water, two smolts; about 3 inches long, were put by boys, out of mere amusement. One of these grew into a salmon, which, when five years old, weighing $I \frac{1}{2} 1 \mathrm{bs}$, was caught and sent to Mr. Stoddart, of Kelso, who had it boiled for dinner. $\mathrm{He}$ reported that it was not unpalatable. The other smolt grew into a bull-trout, and lived for seven years. It died during a very severe winter, when, on account of the water being frozen, it could not be fed.

4. The Duke of Buccleuch's gamekeeper at Bowhill was for some years in the practice of putting a few smolts into a freshwater pond, and feeding them regularly with bullock's liver. If reported that the smolts which grew into salmon throve for about three years, and then died, but that bull-trout smolts kept in good condition for a longer period.

5. Fish marked by wires in the River Tweed, and elsewhere. 


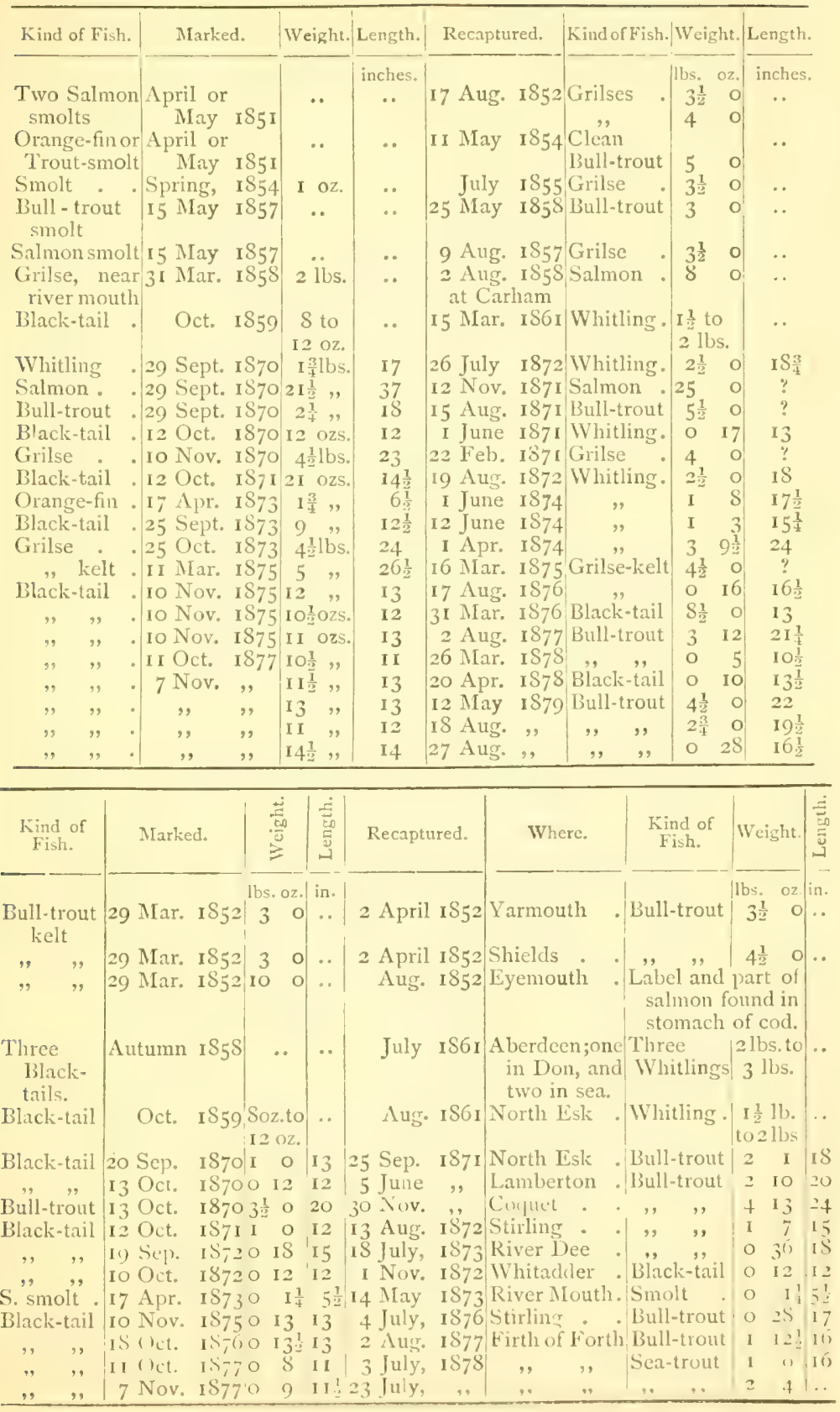




\section{APPENDIX C (see page 21).}

Is the November number of the Fortnightly Rivicu (for $\mathbf{I} S S_{\mathbf{I}}$ ) there is an instructive article on the Salmon Fisheries of Great Britain by Mr. Fred. Eden. The views he expresses will have a useful effect in awakening public interest to a subject of much national importance. Mr. Eden, having acted for several years in all parts of the United Kingdom as Government Inspector and Commissioner, in regard to Salmon Fisheries, has had great opportunity of knowing the condition of those fisheries, and of judging what is necessary for their prosperity.

Mr. Eden is evidently apprehensive that, unless some strong measures are taken, the stock of salmon will soon disappear from our rivers. To prevent this, he says it is absolutely necessary to lessen the catch of salmon. With that view he recommends the entire stoppage of net fishing in rivers, except where the tide reaches; and even in tidal waters, he is for prohibiting night fishing. Another suggestion he makes, is the formation of a central office, so that, instead of "separate establishments and different officials for each of the three kingdoms," there should be more uniformity of management, by what he calls a "consolidation of the Fishery Offices," viz. by the creation, as I suppose, of an office in London.

Mr. Eden regrets that he is unable to supply statistics, or any official evidence, to justify his convictions as to the unprosperous condition of our fisheries; no small proof, by the way, of the lamentable absence of information regarding an important national industry, which every well-constituted Government ought to possess.

Some amount of statistical information, however, may be obtained from the official record kept at Billingsgate Market, of the number of boxes of salmon which arrive there from different parts of the United Kingdom. True, London is not the only large town to which British salmon are sent for sale; but it receives an 
immensely larger supply than any other town; so that if its market records distinguish the different divisions of the United Kingdom from which the supplies come, any considerable increase or decrease of these, through a series of years, will indicate a change in the productiveness of our rivers.

The number of boxes from Scotland for the years 1877,1878 , I879, and 1880 , were respectively $28,189,26,465,13,929$, and $\mathrm{r} 7,408$. The average of these four years is $2 \mathbf{r}, 497$. But in looking back to the previous six years' returns, it is found that the average of these six years was 26,038 boxes. In one of these six years, the number of boxes exceeded 3I,000.

This diminution in these ten years is the more remarkable, because during that time the numbers of nets and of improvements in the modes of fishing have been constantly increasing.

It is a further indication of the unprosperous condition of the Scotch Salmon Fisheries, that, about a year ago, an association for the improvement of these fisheries was formed, with the 1)uke of Sutherland at its head, and with a council of influential proprietors, all more or less interested in the preservation of the Scotch Salmon Fisheries. This association, with a membership already of $\mathrm{I} 59$ persons, and supported by 69 local angling clubs, could scarcely have obtained such immediate and influential support, had there not been a strong and general conviction on the part of the Scotch public, that our salmon fisheries are in a very unprosperous state.

One of the first acts of this association was to send out a circular to the chief constables of counties, asking, "Whether there are any rivers in your county, which were formerly frequented by salmon, but in which they are not now to be found; and if there be such, what are the canses which, in your opinion, now prevent salmon entering them?"

The answers to this circular showed, "that in scven countics salmon appear to have forsaken rivers formerly frequented by them." The names of these seven counties are enumerated in the lately printed and published report of the association.

These answers further state, as probable causes of this desertion of rivers by salmon, pollutions, obstructions, and poaching. 
Another query put to the chief constables was to ascertain if "proper arrangements cxist for the proper observance of the provisions of the Salmon Fishery Acts of $\mathrm{I} 862$ and I868, for the protection of salmon in the salmon rivers of your connty?"

From the answers to this query, it appeared that in eight countics (the names of which are given), each containing several fishery districts, no Fishery Boarls cxist. In one of these counties, there are no less than thirty-two salmon rivers; and in another county (but not one of these eight), viz. Argyll, where there are also thirty-two salmon rivers, there is only one Fishery Board, viz. in the Island of Mull. It appears that, in terms of the Salmon Act of $\mathrm{I} S 62$, the whole of Scotland was perambulated by Government Commissioners, with the view of officially determining the districts in which Fishery Boards were to be formed. The districts fixed on by these Commissioners numbered 105 , each of course containing one or more salmon rivers. The Sheriffs of Counties, by appointment of Government, summoned the fishery proprietors in these districts to meet, with the view of forming Boards; but in most districts the call was not responded to; and at present there are no more than about twenty Fishery Boards altogether, independently of the Tweed Commissioners.

It is true that the absence of Fishery Boards in some districts is there partially compensated for by such protection as can be afforled by individual proprietors, through whose property, or part of it, salmon rivers run. This is the case in Sutherlandshire, and in some parts of Inverness-shire, Ross-shire, Perthshire, Elgin, Argyllshire, and Caithness. Their protection of salmon is of course less efficacious than that of Statutory Boards. But supposing their protection were as good, the fact remains, that there are at least two-thirds of the Scotch salmon rivers without any protection against pollutions, obstructions, and poaching.

Therefore, the first point of inquiry surely should be, why has the scheme of protection introduced by the Government Salmon Acts of IS6z and I $S 6 S$ so completely failed; and why should no less than twelve years have been allowed to elapse, without any remedy being applied, or even proposed?

It appears that, in or shortly before the year 1870 , this fact of 
failure had become known to Government; for special Comnissioners were in that year appointed to inquire into the matter, and report on "the effect of recent legislation on the Salmon Fisheries in Scotland." Lord Aberdare, who was then Home Secretary, directed the attention of the Commissioners to various points, and among them the following :-

"As to local fishery managenent; hozo far are District Boards in operation, and whether any alteration in their constitution is desirable?"

The two Commissioners appointed to make this inquiry were the late Dr. Frank Buckland, and Mr. Archibald Young, the present Fishery Inspector for Scotland.

They state in their official Report, that, to enable them to obtain the requisite information, they sent to District Boards and to proprietors, as well as to tacksmen of salmon fisheries, circulars containing thirty-six queries, to most of which answers were received.

The Commissioners say that they afterwards personally inspected the principal salmon rivers in Scotland, forty-six in number, and had personal meetings with twenty-two District Boards, and with a number of landed proprietors interested in the fisheries.

On the point above referred to, the Report bears, that whilst the number of Fishery Districts designated by the Commissioners under the Acts of I862 and I 868 was 105 , "at this moment there are not above 30 District Boards constituted and working !"

The Commissioners in their Report suggest, as a cause for this failure of the scheme of Fishery Boards, "the smallness of many of the districts, and the poverty of the fishings ;" explaining this by adding, that "such comparatively trifling streams as the Alness, Armadale, Aylort (and ten others named), and many others, have each been formed into a separate district."

The Commissioners do not point out how "the smallness" of a district, and the "poverty of the fishings" in that district, prevented the formation of a Board. But it is presumed, what they mean is, that when the rent or value of the fishings in any particular river is so small, that no reasonable rate of assessment would be sufficient to pay the expense of a Board (with a clerk to record proceedings and levy assessments, as also to pay watchers and 
conduct prosecutions), the formation of a Board was felt to be impracticable.

With the view of meeting this difficulty, the Commissioners suggested, that " if the system of District Boards is to be carried out and extended, we are of opinion that many of the smaller adjacent districts might be advantageously combined."

It will be observed that the Commissioners, in offering this suggestion as a remedy, speak of it in no terms of confidence. Undoubtedly some expense would be saved by having one clerk for a district embracing three or four Boards. But, on the other hand, the greater distances which members of such a Board would have to travel, might prevent attendance at meetings; and the rivers in the enlarged or combined district might still yield so small a rental, that any reasonable assessment on that rental would not provide watchers for all the rivers.

The Commissioners, apparently from want of faith in the efficacy of Fishery Boards, even when combined, referred to another plan, by stating that " it has likewise been proposed, that inspectors should be appointed, as in England, who should excrcise the power's of District Boards in those districts where Boards do not exist, and who should have a seat at meetings of District Boards, but no vote."

And this suggestion the Commissioners, at the conclusion of their Report, actually adopt as a recommendation to Government, in the following terms, viz. "that Government Inspectors should be appointed, to enforce the provisions of the Salmon Fishery Acts in districts where Boards have not been constituted."

But this recommendation seems one of doubtful practicability. In the first place, though it is said that in England, Fishery Inspectors exercise the powers of District Boards, the evidence of this statement is not referred to. In the second place, when it is said that the Government Inspectors are to "exercise the powers of Boards," and "enforce the provisions of the Salmon Acts," how can these powers be exercised by an official residing in Edinburgh? Is he, in the absence of any Fishery Board in a district, to appoint watchers for the rivers there?-or order prosecutions?-or levy assessments? 
The Commissioners having consulted such District Boards as were in existence when they drew up their Report, it may be useful to see what answers these Boards gave, bearing on local management.

In reference to the query, "Is the constitution of District Boards satisfactory, as regulated by 25 and 26 Vict., cap. 37 (1862), and 3 I and 32 Vict., cap. I28 (1868)? If not, state what improvenents you would suggest, and why?"

From the Forth District an answer came containing the following statement:- "It should be made obligatory on proprietors of salmon fishings to appoint and maintain efficient District Boards, unless it be intended to depute their powers to Government Inspectors. At present there are no District Boards in the great majority of the salmon fishery districts. But even if there were, for all the rivers, $I$ think it absolutely necessary that there should be qualified inspectors, with power to examine and inquire into all fisheries, and cause the enactments relating to them to be carried out." "The absence of authoritative inspection is a direct encouragement to neglect of the regulations."

From the Tay District an answer came containing the following statements:- "I am opposed to the manner in which District Boards are constituted. No Board with four to three can be a fair tribunal. Boards should be constituted of an equal number of upper and lower heritors, their chairman having a deliberative but not a casting vote. Instead of Boards, I would rather give the management of the fisheries to two paid Commissioners, provided they had ample powers."

"District Boards should not have direct authority, but should report to a Central Board in Edinburgh. Some means should be devised for preventing individual interests being prejudicial to the general good of the fisheries in the district."

"Six members are sometimes more than can be found in the district of a small river. Again, six members are fewer than will admit of all the interests of a larger district being fully represented."

From the South Esk District an answer came containing the following statements:-_ I consider District Boards of little use, 
except to give information to a Government Commissioner who knows his work, and has power to enforce the law."

Another proprietor wrote: "I do not approve of Boards. There ought to be Government Inspectors, independent of the proprietors. The inspectors should make an examination of the river at least twice a year-the proprietors and tenants, using the weirs and exercising the right of fishing, being subject to his orders, with a right of appeal to the Sheriff."

Another proprietor wrote as follows:-The Board, of which I am a member, is utterly useless; the proof of which is, that there is here a good salmon river without salmon, at least above Brechin. The members cannot be got together. We don't understand all matters connected with salmon fishing, and we don't like to interfere with our neighbours. None of the upper proprietors think of attending the Board meetings, because there is no salmon fishing above Brechin; so the lower proprietors are allowed to do as they like."

From the Ness District the following remarks came:- "The constitution of the Boards is not satisfactory. The districts also are badly arranged. The Boards are formed on the principle of having all matters relating to the fisheries conciucted by fishery proprietors, and giving a completely preponderating interest to the upper as against the lower proprietors, or the reverse, without any representation of the public interest. The Boards should be composed in whole, or at least to the extent of two or three members, for each district, of Government Commissioners; and the existing arrangements for giving a dominating influence to one class should be abolished. The district should also be enlarged. I think the Ness, Beauly, Conon, and Nairn, and their tributaries, should form one district, and a specified number of members should be entitled to call meetings, or require the clerk to do so."

Another proprietor in the Ness District wrote as follows:"All fishery proprietors should have a voice at the Board, or else be exempted from taxation.

"I suggest also that a district. embracing several rivers, such as the Ness, might advantageously be placed under the management 
of some intelligent person, who should have power to make alterations in the bed of the river, so as to increase its productive power as a spawning bed, or to improve its capabilities for angling by stoning it, \&c. At present, proprietors are chary of doing anything at their own expense, because other people may benefit by it as much as they, without incurring expense."

Another proprietor in the Ness District wrote:- "The Board loes not work satisfactorily, the whole power being vested in the upper proprietors, since they succeeded in depriving me of the chairmanship, by reducing my rent from the highest in the district to its present low rate. Under present circumstances, upper and lower proprietors can scarcely agree."

From Naim Fishery District the following remarks came:"A Board has been constituted, but is not in a working state." "The Nairn will never be a fishing river. It is valuable only for breeding."

From Lochy Fishery District the following remarks came :"Undue weight and importance is given to the proprietor who has the largest rental, as regards his right to sit as chairman, with a deliberative as well as a casting vote. The consequence is, that he assumes and acts as an autocrat."

From Creran District the following came:- "There is no Board here. The formation of a Board should be compulsory; or proprietors who assess themselves for the protection of the fishings should be entitled to exercise all powers for the protection of the fish, without the interference of those proprictors who consider their fishings valueless. At present, those who wish to protect the salmon are prevented by others, who have little interest in the fish."

From Awe District the following answer came :- "This Board may illustrate the working of Boards as constituted under the Acts. There are two upper and two lower proprietors on the Board, the chairman being a lower proprietor, and having a casting vote. One of the upper proprietors has not been represented at the Board, but should be. The lower proprietors could have carried any measure against the upper, who have therefore practically no power to compel the Board to carry the Act into 
execution. Hitherto the upper proprietors protected the fishings, while the lower proprietors have got the fish. It is in the interest of the upper proprietors that additional measures are required."

From Shicl District the following answer came:- "There is no Board;-but some authority should exist. Probably, if districts were larger, the formation of a Board would be easier; but I believe inspectors would be better than a Board, every member of which is more or less influenced by his own interests, while inspectors would be influenced only by the public good."

From Findhom District the following answer came:- "Our Board seldom meets, and the control is much in the hands of the chairman, who occupies that position as having the largest (netting) interest. Of course the tendency is to work against the interests of upper proprietors, if they are conflicting with those of the lower proprietors. The Board must be one-sided, the chairman having the casting vote. But they are too much onesided, and unnecessarily so."

From Clyde and Leven District the following answer came:-"A Board was constituted, but it was never set working. Proceedings were taken in Court by Sir James Colquhoun, and he got the Board quashed."

From Doon District the statement came that the Board, "being found to be unworkable, was allowed to lapse."

From Conon District the answer was, that "a Board was constituted, but it became extinct."

The following suggestion came from the Lochy District Board, viz. - "There should be a staff of marine watchers, provided with a steam launch, to put down the depredations upon salmon committed by trawlers within the southern limits of the district of the River Add, and the point of Ardnamurchan.

"This provision is necessary, owing to the prevalence of the capture of salmon in the Sounds of Jura and Scarba, Loch Linnhe, the Sound of Mull, and the numerous arms of the sea opening therefrom. These watchers should be under the control of a general Board." 
On a review of the information and suggestions contained the foregoing memoranda, it will be seen-

Ist. That the plan of entrusting to Fishery Boards the carrying out of the provisions of the Scotch Salmon Acts of $186 z$ and 1868 has almost entirely failed.

Some of the principal rivers in Scotland, viz. the Tweed, Forth, Tay, North Esk, South Esk, Dee, Don, Deveron, Ythan, Finclhorn, Spey, Ness, and Lochy, are under the management of Fishery Boards or individual proprietors; but apparently all the rest of the Scotch salmon rivers are under no protection whatever.

2nd. That in the Fishery Boards which exist, there is evidence of want of harmonious action, on account of the diversity of interests of the members; one half of the members consisting of upper proprietors, who seldom see salmon, except in close-time, when they cannot legally be caught; and the other half consisting of lower proprietors, who possess all the fishings of any value.

3 rrl. That almost all the Fishery Boards, apparently conscious of their inability duly to carry out the provisions of the Salmon Acts, suggest the appointment of Government Inspectors, not only to visit the districts and assist Boards with their advice, but even to exercise powers for enforcing observance of the law.

Some of the answers sent by the Boards to the Commissioners' circular, bear on the constitution of the Boards, and are deserving consideration, in reference to the question whether any attempt should be made to continue the existing system of Boards. By the provisions of the Salmon Acts, the Boards must consist of two sets of proprietors-called in these Acts the upper and the lower proprictors. The greatest number of each set is required to be three; and if there be less than three in either the upper or the lower part of the river, the number of members on the Board must then be four, viz. two of each set. Curiously enough, the Boards are not allowed to elect a chairman; nor is a chairman selected for them by any one who might judge of his qualifications. The Act appoints as chairman the proprictor who has the largest fishery rental or value in the district, ignoring altogether any other test of suitability. 
Now, it is important to observe that the interests and duties of these two sets of proprietors are not only different, but adverse to each other. Each set, of course, wishes to capture as many salmon as they can. For this purpose the lower proprietors wish to detain the fish in the lower parts of the river by allowing or tolerating obstructions, natural or artificial, which prevent the fish ascending to the higher reaches. On the other hand, the upper proprietors desire the removal of such obstructions ; and especially as the expense of removing them would fall chiefly on the lower proprietors, on account of their larger rentals. Many examples of contention on this account, between the two sets of proprietors, are afforded by the answers from several of the Districts.

In these conflicts the lower proprietors generally can outnumber the upper proprietors; as even though one of the former should be absent from a meeting, the chairman naturally sides with them, and he has a casting as well as a deliberating vote.

In the answers from the Boards, it is frankly admitted that, each set of proprietors generally fight on behalf of their own individual interests, and that the interests of the public are overlooked. Whilst it is the object of each set of proprietors to catch as many fish as they can, it is the interest of the public, that the numbers caught should not be so great as to exterminate the stock, on the well-recognised principle, that profits ought to come out of yearly dividends, and not out of capital.

It is, however, only fair to the Boards to add, that many of them, as if sensible of the almost unavoidable tendency of members to attend chiefly to the interests of their own parts of the river, suggested that, instead of Boards, there should be inspectors, appointed by Government, with ample powers to devise and carry out measures of management which the Boards, constituted as they were, found themselves unable to adopt.

Perhaps it may be asked, why should there have been so complete a failure of protection by means of local Boards in Scotland, when a similar system of Boards prevails successfully in England and Ireland?

On the other hand, it is not incorrect to affirm, that even in England and Ireland the action of the River Conservators has 
not always been smooth. The jealousies and sparring of upper and lower proprietors on these Boards, are occasionally referred to by the late Dr. Buckland in his Annual Reports. But in England and Ireland the local Boards have several advantages over those in Scotland, to secure harmonious action.

In the first place, there are Government Inspectors in England and Ireland, men of great intelligence, experience, and social weight, whose duty it is, and whose practice it has been, to assist Boards by their advice, and also to visit districts, when personal inspection is necessary.

In the second place, the funds at the command of the Boards in England and Ireland are not raised by assessment on the members of the Boards, as under the Scotch Acts. The funds are, in both of these countries, raised by means of licences, which have to be taken out for the use of nets, boats, and rods, and the dues for which are mostly paid by persons not members of the Boards. The amount of licence dues paid in the year I 880 for

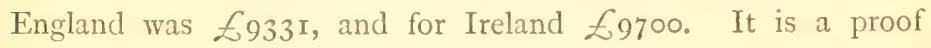
alike of the efficiency and popularity of licences in England, that two years ago that system was extended to include angling for trout, which (at only I $s$. per rod) in England already yields a yearly income of above $\mathcal{L}_{1500}$.

Then, besides the funds raised by licences, there is in Ireland important assistance given by the Coast-Guard for repressing poaching along the sea coast, and by the Constabulary for punishing persons guilty of polluting rivers.

In the third place, the Government Inspectors in England and Ireland draw up annual reports, to be laid before Government and Parliament, in which not only is there information respecting the state of the fisheries generally, but particular information of the operations of the local Boards in charge of the different rivers.

In the fourth place, it should be recollected that Scotland, especially in the Highland districts, is less densely peopled by resident proprietors than England and Ireland. 'The distances which members have to travel, to attend Board meetings is, therefore, much greater in many parts of Scotland, than in the other divisions of the kingdom. 
Notwithstanding this last drawback, it is very probable that, were arrangements introduced similar to those in England and Ireland, the system of Fishery Boards in Scotland might be continued, and steps taken to extend them. Especially is it desirable to adopt some other plan of raising funds than by obliging the members of Fishery Boards to assess themselves and their neighbours. It is scarcely reasonable to expect, that proprietors of fishings, especially when their fishery rental is small, will voluntarily constitute a Board, whose proceedings would involve the members, not only in the expense of employing watchers, but in legal proceedings for removing obstructions, stopping pollutions, \&c.

The aversion to such self-imposed assessments is all the more natural, when it is remembered how heavily taxed all subjects entered in the valuation rolls of Scotch counties are, for police, prisons, lunatic asylums, poor rates, schools, \&c. \&c.

Another valuable suggestion may be obtained, from the mode of constituting the Boards of Conservators in England. There the Boards include three classes of persons: first, owners or tenants of fisheries in the district, not below a certain yearly value or river frontage; second, persons selected by the Justices in Quarter Sessions, the number being previously determined by the Home Secretary; and, third, persons selected by those holding licences for fishing in the district, the number depending on the money value of the licences. In Scotland, under the Salmon Acts, the Fishery Boards consist entirely of proprietors, in respect merely of being connected with those parts of the river which put them into antagonism with one another. In England, whilst some of the members are on the Board in respect of being owners or occupiers of fishings above a certain standard, the majority of the members are elected and selected with no other qualification except fitness for the duty, in the opinion of those appointed by law as thought competent to judge.

The constitution of the English Fishery Boards is therefore, in principle, greatly superior to that of the Scotch Boards; and in any future legislation for Scotland, this point should be kept in view.

Above all, there should be for Scotland an appointment of 
official inspectors, with the powers and duties of the inspectors in England and Ireland. For England, there are two most able and intelligent inspectors (Mr. Spencer Walpole and Professor Huxley), each with a salary of $£ 700$ yearly, a Government office in London, and a secretary, who has a salary of $£ \mathrm{I} 60$ yearly. For Ireland, there are three inspectors, equally able and intelligent, Major Hayes, Mr. Brady, and Mr. Johnston, each with a salary of $£ 700$, a Government office in Dublin, and a secretary, who has a salary. These inspectors are in frequent communication with the District Fishery Boards, not only by correspondence, but by personal visits to the rivers, and thereby afford to the Boards much valuable advice and assistance.

Why should there be no similar arrangement for Scotland? The following estimates have been given of the yearly value of the Salmon Fisheries in the three divisions of the kingdom :-

\begin{tabular}{|l|c|c|}
\hline & $\begin{array}{c}\text { By Mr. Caird } \\
\text { in } 1868 .\end{array}$ & $\begin{array}{c}\text { By Mr. Young* } \\
\text { in } 1877\end{array}$ \\
\hline England . . . . & 6.000 & \multicolumn{1}{c|}{6.} \\
Ireland . . . . & 320,000 & 400,000 \\
Scotland . . . . & 200,000 & 250,000 \\
\hline
\end{tabular}

These figures are surely sufficient to establish the importance of the fisheries in each division of the kingdom.

If the preservation of salmon in our country be allowed to be an object of national importance, why should the same means for attaining that object, adopted in England and Ireland, not be applied to Scotland?

The obligation of Government to look after those fisheries, which afford alike a large supply of wholesome food to our population, and means of extensive employment to the industrial

* The figures in this table are taken from Mr. Young's Treatise on Salmon Fisheries in Stamford's series of 'British Industries.' It is understood that Mr. Young's information was derived from official returns, so far as regards England and Ireland; and, as regards Scotland, from his own personal knowledge of the Scotch rivers, and retums furnished by clerks of District Boards. 
classes, has been so far acknowledged, and so far fulfilled for Scotland, that a Board many years ago was established in Edinburgh for the "encouragement and better regulation" of Herring Fisheries, by enforcing the provisions of various Acts, which fix an annual and weekly close-time, specify the size of the meshes of nets, and require registration of boats. The Act of Parliament also places at the service of that Board a gunboat, with a crew and an officer of the Navy, to assist the Board in the execution of its duties. In connection with this object, offices are provided in a Government building in Edinburgh, with a secretary, two clerks, two general superintendents, and upwards of thirty local inspectors. By establishing such a department, Government and Parliament have acknowledged the obligation to look after and regulate our Scotch Herring Fisheries. Are Salmon Fisheries not equally entitled to State protection? Of late years, Government and Parliament have been extending protection to other wild animals of very inferior importance, such as crabs, mussels, oysters, seafowl, and land birds, fixing a close-time for each, imposing a penalty on offenders, and authorising the Procurator-fiscal to prosecute, at the public expense. Looking to these facts, why in the case of salmon should the State throw on individuals the duty and expense of prosecuting persons who violate the provisions which the State chooses to enact? Salmon, whether in the sea or in rivers, are no more private property than herrings. They are the property of the Crown, and no riparian proprietor, either on our rivers or on the sea-coast, can fish for salmon except he can show a grant or a lease from the Crown. But the Crown does not thereby divest itself of the obligation to preserve from extermination, what it has leased or what it keeps in its own hands in trust for the nation.

On these grounds, it is hoped that Government and Parliament will feel it to be a duty to devise better means of protecting salmon in Scotland than at present exist; and for this an opportunity is afforded by the fact of there being already in Edinburgh a Board of Fishery Commissioners, occupying apartments in a Government building, where there is sufficient space for an additional office applicable to Salmon Fisheries. 
As in this Paper on behalf of Scotch Salmon Fisheries, the appointment of inspectors has been urged, with powers similar to those of the inspectors in England and Ireland, it would be wrong to conclude without adverting to Mr. Eden's disapproval of having separate inspectors for each division of the United Kingdom. He says, at present "there are separate establishments and different officials for each of the three kingdoms. But one policy, and one set of men to carry it out, would tend largely to efficiency and economy." He adds, that "by consolidation or amalgamation of the Fishery offices, uniformity of management would be obtained." (Page 639.)

If Mr. Eden means that there should be only one set of inspectors for the whole kingdom, with offices in London, it seems very doubtful whether either efficiency or economy would be thereby secured. Surely inspection would be both more efficient and more economical, were the officials for Ireland to reside there, with an office in Dublin, and those for Scotland to reside there, with an office in Edinburgh, where they would be nearer to their work. "Uniformity of management," which Mr. Eden deems of importance, could quite well be secured, by the same instructions being issued by Government to each set of inspectors.

One of the greatest disadvantages to which the Scotch fisheries and Fishery Boards are exposed, is the non-existence of any inspector to visit the Fishery districts, and collect materials for framing an annual report. A still greater service would be rendered were Inspectors appointed with power to visit the districts and attend Meetings of the Board, as ex-officio members.

Now that the utter failure of the Fishery Board system, and the non-existence and need of an efficient inspector in Scotland has been made publicly known, a heavy responsibility will lie on Government if steps are not immediately taken to provide a remedy.

There ought to be the less hesitation on the part of Government to devise some measure for affording protection to the Scotch Salmon Fisheries, that, during the last twenty years, owing to the assiduity of the officers connected with the Woods and Forests, the revenue now drawn for the Crown from these fisheries is very considerable, and is every year increasing in amount. The 
Commissioner entrusted with this duty made most searching inquiries along the sea coasts, and also along river banks, to ascertain whether the proprietors who claim salmon fisheries there could show a legal title to them. Much irritation was caused by these proceedings; and it seems not unreasonable that, in respect of the revenue obtained by the Crown from Scotch Salmon Fisheries, the Executive Government should not grudge the expense of affording the means of additional protection.*

This is a practical question which may well be pressed on the attention of Her Majesty's Government. The Association recently formed for the improvement of Scotch Salmon Fisheries would render signal service to the country, by appointing a deputation to wait upon the Home Secretary, to urge that steps should be taken for remedying evils, officially made known to Government twelve years ago, and now attempted to be more fully explained in the foregoing pages.

* It is said, that the amount of Salmon Fishery Rents now drawn by the Crown in Scotland amounts to about $£ 7000$; and that they are annually increasing. 


\section{OFFICIAL PUBLICATIONS} \\ INTERNATIONAL FISHERIES EXHIBITION,}

PUBLISHED BY

WM. CLOWES \& SONS, Limited, 13, Charing Cross, S.W.

(And Sold at their Stalls near each Entrance to the Exhibition.)

\section{OFFICIAL GUIDE BOOKS, \&C.}

LARGE PLAN and TOUR of the BUILDINGS, 1d.; post-free $1 \frac{1}{2} d$.

GUIDE to the EXHIBITION, 3d.; post-free 4d. PROGRAIIME of MUUSIC, \&c., 2d.; post-free 3d. OFFICIAL CATALOGUE, Second Edition, 1s.; postfree 1s. 4d.

CHEAP RECIPES for FISH COOKERY. Prepared by Mrs. CHARLES CLARKE. 3d.; post-free $4 \mathrm{~d}$.

\section{THE FISHERIES PORTFOLIO:} CONTAINING

Ten Original Etchings of Scenes on the British Coast. TITLE. ARTIST.

I.-Bait Gatherers - . . . R. W. MAcbeth, A.R.A.

2.-Running Ashore . . . . Colin Hunter.

3.-A Fisher Girl . . . . . J. D. Watson.

4.-Fishing Boats off Hastings - David LAw.

6.-Going for Bait . . . . . OTTO LEYDE, R.S.A.

6.-Boat Building on the Yare . . C. J. WatTs.

7.-Preparing for Sea-Hastings . C. P. SLocombe.

8.-Ramsgate Harbour . . . . . J. P. Heseltine.

9.-Fisherman's Haven . . . . J. MacWhirter, A.R.A.

10.-Stranded-Rye. . . . . . WILFRID W. BALL.

Price 15 s. the complete set.

LONDON : WILLIAM CLOWES \& SONS, LIMITED, INTERNATIONAL FISHERIES EXHIBITION, \& I3 CHARING CROSS. 


\section{OFFICIAL PUBLICATIONS.}

The following Handbooks upon subjects cognate to the International Fisheriac FunihiLin or in active prepar:

\section{Demy 8vo., in. Illust:}

THE FISHERY L

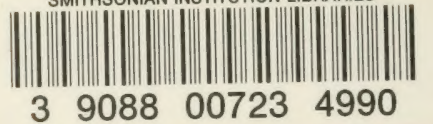

2s. each.

Barrister-at-

Law, M.A. (Oxon.), Hon. LL.D. Edin. ; Corpus Christi Professor of Jurisprudence in the University of Oxford.

ZOOLOGY AND FOOD FISHES. By GeORge B. Howes, Demonstrator of Biology, Normal School of Science, and Royal School of Mines, South Kensington.

BRITISH IMARINE AND FRESHWATER FISHES.

(Illustrated.) By W. SAville KenT, F.L.S., F.Z.S., Author of Official Guidebooks to the Brighton, Manchester, and Westminster Aquaria.

APPARATUS FOR FISHING. By E. W. H. HoldsworTh,

F.L.S., F.Z.S., Special Commissioner for Juries, International Fisheries

Exhibition; Author of "Deep Sea Fisheries and Fishing Boats," "British Industries-Sea Fisheries," \&c.

THE BRITISH FISH TRADE. By His Excellency SPENCER

WALPOLE, Lieut.-Governor of the Isle of Man.

THE UNAPPRECIATED FISHER FOLK, By JAMES G. Bertram, Author of "The Harvest of the Sea."

THE SALIMON FISHERIES. (Illustrated.) By C. E. FRyer. Assistant Inspector of Salmon Fisheries, Home Office.

SEA IMONSTERS UNIMASKED. (Illustrated.) By HENRY LEE, F.L.S.

THE ANGLING CLUBS AND PRESERVATION SOCIETIES OF LONDON AND THE PROVINCES, By J.P. WhEELDON, late Angling Editor of "Bell's Life."

INDIAN FISH AND FISHING. (Illustrated.) By FRANCIS DAY, F.L.S., Commissioner for India to International Fisheries Exhibition.

A POPULAR HISTORY OF FISHERIFS AND FISHERMEN OF ALL COUNTRIES, FROM THE EARLIEST TIMES. By W. M. AdAms, B.A., formerly Fellow of New College, Oxford; Author of 'Zenobia : a Tragedy,' and inventor of the Colometer.

FISH CULTURE. (Illustrated.) By FRANCIS DAv, F.L.S., Commissioner for India to International Fisheries Exhibition.

IN THE PRESS.

FISH AS DIET. By W. Stephen Mitchell, M.A. (Cantab.) ANGLING IN GREAT BRITAIN. By WILLIAM SENIOR ("Red Spinner").

FDIBLE CRUSTACEA. By W. SAville Kent, F.L.S., F.Z.S., Author of Official Guidebooks to the Brighton, Manchester, and Westminster Aquaria.

THE LITERATURE OF SEA AND RIVER FISHING. By John J. Manley, M.A. (Oxon.)

SEA FABLES DISCLOSED. By HENRY LEE, F.L.S.

FOLK LORE OF FISHES: their Place in Fable, Fairy Tale, Myth, and Poetry. By Phil Robinson.

THE OUTCOME OF THE FXHIBITION. By A. J. R. TRFNDELL, of the Inner Temple, Barrister-at-Law, Literary Superintendent for the Fisheries Exhibition.

LONDON :

WILLIAM CLOWES AND SONS, LIMITED, INTERNATIONAL FISHERIES EXHIBITION, \& 13, CHARING CROSS. 